\title{
STUDENT ARGUMENTATION SKILL ANALYSIS OF SOCIOSCIENTIFIC ISSUES IN SOLVING ENVIRONMENTAL PROBLEMS
}

\author{
Rita Istiana ${ }^{\text {a) }}$, Desti Herawati ${ }^{\text {a) }}$

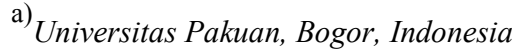 \\ Corresponding Author: rita_istiana@unpak.ac.id
}

Article history: received 07 January 2019; revised 27 January 2019; accepted 01 February 2019

\begin{abstract}
This is a mixed method-explanatory research. This study aims to obtain information about the relationship between the ability to solve environmental problems with students 'argumentation skills about socio-scientific issues and the reasons why the variable ability to solve environmental problems has a very high relationship in improving students' argumentation skills about socio-scientific issues as well as other factors that influence it in addition to the ability to solve environmental issues. This research was conducted in November 2017 until May 2018. The population of this research is Biology Education Student, FKIP, Universitas Pakuan academic year 2017/2018. Sampling technique using purposive sampling and Slovin. The sample of 113 students consist of semesters 2 to semester 6 . Based on the result of significance test and linearity test it can be concluded that simple regression analysis with equation $\hat{Y}=0,898+0,049 \mathrm{X}$ is significant and linear. Based on the results of quantitative research obtained correlation coefficient (ry) between the ability to solve environmental problems with student argumentation skills about socio-scientific issues of 0.765 . The value of this correlation coefficient shows that the null hypothesis $\left(\mathrm{H}_{0}\right)$ is rejected and the alternative hypothesis $\left(\mathrm{H}_{\mathrm{a}}\right)$ is accepted, it means that the ability to solve the environmental problems contributes very highly to students' argumentation skill about socio-scientific issue. Based on the results of interviews on several sources, there are other factors that influence students' argumentation skill about socio-scientific issues among others, confidence, lecturer role, and peer role during discussion.
\end{abstract}

Keywords: ability to solve environmental problems, argumentation skills, socio-scientific issues

\section{INTRODUCTION}

The scientific argument is thinking skills which are considered as the main objective of improving science education (American Association for Advancement of Science [1]; National Research Council in Furtak[2]). Duschl and Gitomer (in Furtak, [2]) reveal that the improvement of education involves the development of thinking, reasoning, and problemsolving skills to prepare students to participate in making and evaluating claims of scientific experiments, explanations, models, and design experiments. Habits argue important in everyday life because these arguments play a role in making correct and logical decisions about controversial issues (Yang \& Tsai [3]). Therefore, efforts need to be made to increase human resources to become individuals who are skilled in argumentation by applying scientific concepts, principles, and practices to issues that are also influenced by social, political, ethical, and/or economic considerations.

The research conducted by Herawati [4] shows that in general students have been able to reveal claims accompanied by data and/or warrant in arguments, but scientific concepts/facts are used as data, and student arguments that link data with claims are still many invalids, rational, and relevant so that the arguments produced by students are weak arguments. The results of this study are also in line with the research of Ardianto and Herawati [5] which states that the quality of student argumentation is still at level 2, meaning that students are only able to express claims and reasons in arguing but are less skilled in providing empirical evidence. These studies show the low quality of student argumentation.

The low quality of student argumentation is caused by biology learning which is not in accordance with the nature of science. Based on the results of the field study shows that the learning that has been done by students is more emphasis on minds on. Student skills in the problem-solving learning process about socio-scientific issues related to environmental problems are rarely trained in lectures. This fact is thought to be the cause of students' low skills in identifying scientific issues and causing students to be less skilled in asking questions that need to be investigated and lacking in providing real solutions. This finding is reinforced by data showing that $57 \%$ of students feel the learning process does not use problem-based learning methods.

Based on the description above, the problem in this study is whether there is a relationship between the ability to solve environmental problems and the skills of student argumentation on sociosantific issues and what other factors besides these variables play a role in improving students' argumentation skills about sociocritical issues. 


\section{RESEARCH METHODS}

This research was conducted at the Biology Education Study Program, Faculty of Teacher Training and Education, Pakuan University 2017/2018 academic year. The research began from November 2017 to May 2018. The method used in this study was sequential explanatory combination research, the sequential explanatory combination research method is a research method that combines quantitative methods and qualitative methods sequentially wherein the first stage the research is carried out using methods quantitative and in the second stage using qualitative methods. The variable of this study consisted of 2 variables, namely the ability to solve environmental problems as independent variables and the skills of student's argumentation about the Sociocritical issue as the dependent variable. The unit of analysis of this study is students of the Biology Education Study Program, Faculty of Teacher Training and Education, Pakuan University 2017/2018 academic year. The instrument used in this study tests for both variables.

The population of this study was 160 students of Biology Education, FKIP, Pakuan University, and the research sample was taken using a Purposive Random Sampling technique, with Slovin criteria obtained as many as 113 students. The research instrument was calibrated using 2 Judgment Experts. Data analysis consists of two stages, namely the quantitative stage and the qualitative stage. The Quantitative Phase is carried out to find out the extent of the relationship between variables $\mathrm{X}$ and $\mathrm{Y}$ by testing the hypothesis through regression testing and correlation using SPSS 20. Data and qualitative information are obtained based on the results of interviews, observation, and documentation. Qualitative data is obtained from data reduction, data display, and drawing conclusions.

\section{RESULTS AND DISCUSSION}

In this study, hypothesis testing was done in the form of a correlation and regression test. The data that will be tested consists of two data, namely the ability to solve environmental problems with the skills of student argumentation about sociological issues.

\section{Regression Meaning Test}

Table 1. Results of Calculation of Meaning of Regression

\begin{tabular}{|l|l|l|l|l|l|}
\hline Coefficients $^{\mathrm{a}}$ & \multicolumn{5}{|l|}{} \\
\hline Model & $\begin{array}{l}\text { Unstandardized } \\
\text { Coefficients }\end{array}$ & $\begin{array}{l}\text { Standardized } \\
\text { Coefficients }\end{array}$ & $\mathrm{t}$ & Sig. \\
\cline { 2 - 5 } & $\mathrm{B}$ & $\begin{array}{l}\text { Std. } \\
\text { Error }\end{array}$ & Beta & & \\
\hline (Constant) & .898 & .283 & & 3.173 & .002 \\
\hline KM & .049 & .004 & .765 & 12.513 & .000 \\
\hline \multicolumn{7}{|c|}{ a. Dependent Variable: KA } & \\
\hline
\end{tabular}

From the table above it can be seen that the regression equation $\hat{Y}=0.898+0.049 \mathrm{X}$. Significance value $0,000<0,05$ which means that the equation is significant. Besides that, the linearity test regimen was also conducted to determine whether the $\mathrm{Y}$ top $\mathrm{X}$ regression model was used linearly or not. Figure 1 below can be seen that the regression equation is linear.

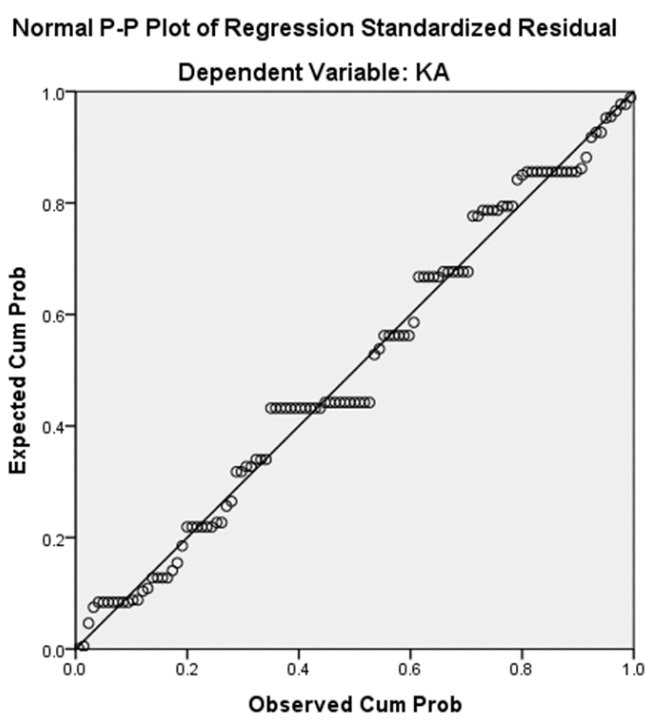

Figure 1. Linearity of Regression

\section{Correlation Test}

After a regression test is then performed to answer the hypothesis a correlation test is conducted to find out how much influence the ability to solve environmental problems variables in improving the skills of student argumentation about the socioscientific issue. Table 2 below shows the correlation coefficient of 0.765 , which means that the ability to solve environmental problems has a very high relationship in improving the skills of student argumentation about the socio-scientific issue. The determination coefficient is 0.585 or $58.5 \%$, which means that the ability to solve environmental problems contributes $58.5 \%$ in improving students' argumentation skills about socio-scientific issues and $41.5 \%$ is influenced by other factors.

Table 2. Correlation Test Calculations

\begin{tabular}{|c|c|c|c|c|c|c|c|c|c|}
\hline \multirow[t]{2}{*}{ Model } & \multirow[t]{2}{*}{$\mathrm{R}$} & \multirow{2}{*}{\begin{tabular}{|l|} 
R \\
Square
\end{tabular}} & \multirow{2}{*}{$\begin{array}{l}\text { Adjusted } \\
\text { R Square }\end{array}$} & \multirow{2}{*}{$\begin{array}{l}\text { Std. Error } \\
\text { of the } \\
\text { Estimate }\end{array}$} & \multicolumn{5}{|c|}{ Change Statistics } \\
\hline & & & & & \begin{tabular}{|l|} 
R Square \\
Change \\
\end{tabular} & F Change & dfl & df2 & \begin{tabular}{|l|} 
Sig. $F$ \\
Change
\end{tabular} \\
\hline 1 & $.765^{\mathrm{s}}$ & .585 & .581 & .40949 & .585 & 156.569 & 1 & 111 & .000 \\
\hline
\end{tabular}




\section{Qualitative Research Results}

The result data of qualitative research are obtained from qualitative data analysis by doing interviews. It includes data reduction activities, presentation, and conclusion. It is carried out after the results of quantitative data. Sub-focus preparation in this study adjusted to the results of qualitative data that had been obtained previously.

Based on the results of quantitative research, the correlation coefficient value obtained between the ability to solve environmental problems and the skills of student argumentation on the socio-scientific issue is 0.765 . This correlation coefficient shows that there is a very high relationship so that the sub-focus in this study will explore the causes of the high relationship between the ability to solve environmental problems with the skills of student argumentation on socioscientific issues and other factors that are expected to have a relationship with students' socio-scientific issue besides the ability to solve environmental problems. The research findings are presented based on data and information from the research sub-focus. The sub-focus of this study is: Why does the ability to solve environmental problems have a very high relationship with the skills of student argumentation about socioscientific issues?

Data and information about sub-focus is obtained based on the results of interviews. The results of the interview are described in the form of presenting data based on the results of data reduction that has been done.

Table 3. Data on Qualitative Results

\section{Quantitative and qualitative relationships between variables}

The analysis of comparing the relationship between quantitative and qualitative data to solve environmental problems with the skills of student argumentation about the socio-scientific issue. The relationship between the variable ability to solve environmental problems with the skills of student argumentation on socio-scientific issues has a correlation of 0.765 .

This reinforced and deepened the qualitative data, namely the existence of a very high relationship between the ability to solve environmental problems with the skills of student argumentation about socioscientific issues due to problem-solving skills. Students are required to analyze the environmental problem in which there is a solution to the problem, and this part can influence someone's argument. When students analyze it, they must look for supporting data. It can also influence someone's argument in conveying the reasons along with the data. The results of qualitative research can expand quantitative data, where in addition to the ability to solve environmental problems that affect the skills of student argumentation on socioscientific issues. There are also other influential variables such as confidence, courage, communication skills, lecturer role in learning and the role of friends in discussion.

From the results of quantitative testing, it is found that the correlation coefficient was 0.765 which means that the ability variable to solve environmental problems has a very high influence in improving the students' argumentation skills about the socio-scientific issue. Students involved in

\begin{tabular}{|c|c|c|c|}
\hline No & Category & Qualitative Results Data & Conclusion \\
\hline 1 & $\begin{array}{l}\text { Understanding } \\
\text { the Problem }\end{array}$ & $\begin{array}{l}\text { If students are able to understand the existing } \\
\text { environmental problems both concepts and } \\
\text { applications, they are able to provide claims on } \\
\text { problems and be able to provide complete data to } \\
\text { express their opinions so that they are able to declare } \\
\text { a valid warrant or claim supported with the right data. }\end{array}$ & Strengthen quantitative data \\
\hline 2 & $\begin{array}{l}\text { Planning } \\
\text { problem solving }\end{array}$ & $\begin{array}{l}\text { When students understand the existing problems, then } \\
\text { they are required to make a problem-solvingplan by } \\
\text { knowing the causes and effects so that students' skills } \\
\text { in providing backing, rebuttal and qualifier can } \\
\text { strengthen their arguments }\end{array}$ & Strengthen quantitative data \\
\hline 3 & $\begin{array}{l}\text { Implementation } \\
\text { of Problem } \\
\text { Solving Intemal } \\
\text { factors }\end{array}$ & $\begin{array}{l}\text { When students are able to provide solutions to } \\
\text { environmental problems. It is one of the important } \\
\text { indicators in arguing. }\end{array}$ & Strengthen quantitative data \\
\hline 4 & $\begin{array}{l}\text { Intemal factors } \\
\text { Confidence, } \\
\text { Activity, } \\
\text { Communication } \\
\text { Skills }\end{array}$ & $\begin{array}{l}\text { Students who dare to express their opinions in public } \\
\text { will increase their confidence even though sometimes } \\
\text { the arguments are not right. }\end{array}$ & Strengthen quantitative data \\
\hline 5 & $\begin{array}{l}\text { Lecturer Roles } \\
\text { in the leaming } \\
\text { process }\end{array}$ & $\begin{array}{l}\text { If leaming is not trained with the discussion of } \\
\text { solutions to real problems in the environment, } \\
\text { students become less accustomed to expressing their } \\
\text { opinions. }\end{array}$ & Narrowing quantitative data \\
\hline 6 & $\begin{array}{l}\text { Friends of the } \\
\text { same age }\end{array}$ & $\begin{array}{l}\text { Friends or partners in the discussion have a positive } \\
\text { influence on the activeness and courage of students in } \\
\text { their opinions. }\end{array}$ & Narrowing quantitative data \\
\hline
\end{tabular}
problem-based learning (PBL) solve problems can present arguments to support their solutions (Brian R. Belland [6]).

Learning problemsolving in group discussions can improve student skills in arguing. Discussions in small groups can reduce disputes and increase the creativity of group members when compared to discussing with large groups because it can lead to disagreements that result in irreverent actions. The teacher's role may encourage students to evaluate ideas carefully, speak politely, and avoid impulsive responses to abusive behavior (Chiu [7]).

Important skills in solving problems, especially structured problems, are the production of coherent arguments for justified solutions and actions. The structured problem-solving groups produce 
broader arguments. When they do solve unstructured problems, the students need more argumentations because of the importance in producing and supporting alternative solutions. This proves that there is a strong influence between argumentation and problem solving (Cho \& Jonassen [8]).

Individuals who have knowledge of environmental concepts that are not supported by their ability to solve environmental problems, they are unable to provide solutions that occur low in argumentation performance (Oh \& Jonassen [9]).

The role of the tutor/lecturer in improving the skills of argumentation is also evident in the provision of training literature studies on cases of sociocritical issues. Reasoning skills supported by literature from previous cases function as problem-solving narratives from students so that they can obtain meaning. So that when students can build an argument to solve a new case (Tawfik \& Jonassen [10]). Instructional designs made by tutors/lecturers also influence students' ability to reason. The more often the lecturer gives a discussion of cases that need to solve the problem, the more trained students will be in the right argument (Tawfik A. A. [11]).

The way to learn by dealing with and resolving conflicts is the best way to learn. The benefits of doing authentic tasks and using students' energy socially are far greater than just learning students about concepts without having to be involved (Fee \& Belland [12]). So that problem-based learning can improve students' argumentation skills.

Self-confidence is another factor that influences one's argumentation skills. This is in accordance with the research (Kintani, Ali, \& Endang [13]) that expresing opinions can increase students' selfconfidence. Self-confidence is a positive assessment of yourself about the ability that is to deal with various situations and challenges and the mental ability to reduce the negative influence of doubts that encourage individuals to achieve success or success without depending on other parties and are responsible for decisions that it has been determined so that this attitude can improve one's decision making (Mirhan \& Jusuf [14]).

In addition to an attitude of confidence, science communication skills are factors that are able to improve one's skills in argumentation. In order for the learning process to take place in a class that can be directed and systematic, the lecturer/teacher must provide more space for students to be active in learning activities and support students to have science communication skills and scientific attitudes (Afriani [15]). Debate and discussion provide exchange facts needed to enable agreement or resolve differences of opinion regarding public issues, provide relevant evidence needed for the public interest so that people are more involved in issues involving mutual interests (Kamaruzzaman [16]).

\section{CONCLUSION}

Based on the results of the study it can be concluded that there is a relationship between the ability to solve environmental problems with the students' argumentation skills about the socio-scientific issue with the regression equation $\hat{\mathrm{Y}}=0.898+0.049 \mathrm{X}$ and the correlation coefficient of 0.765 which means there is a very high positive relationship between the variables of environmental problem-solving ability with the skills of student argumentation about the socio-scientific issue and the coefficient of determination $\mathrm{ry}^{2}=0.585$ which means that the ability to solve environmental problems has an effect of $58.5 \%$ in improving one's argumentation skills.

The results of qualitative research can expand quantitative data, where in addition to the variable ability to solve environmental problems that affect argumentation skills, there are also other influential variables such as self-confidence, the role of lecturers in learning and influence of friends when discussing.

\section{Acknowledgement}

Acknowledgments the authors say to the Pakuan Siliwangi Foundation that has provided financial assistance so that this research can run smoothly.

\section{REFERENCES}

[1] American Association for the Advancement of Science (1990). Science for all Americans. New York: Oxford University Press.

[2] Furtak, E. M., et al. (2008). A Framework For Analyzing Reasoning In Science Classroom Discourse. Paper presented at the Annual Meeting of the American Educational Research Association. New York.

[3] Yang, F.Y. \& Tsai, C.C. (2010). Reasoning about science-related uncertain issues and epistemological perspectives among children. Instructional Science, 38, 325-354.

[4] Herawati, D., Widodo A., Riandi, \& Rochintaniawati D. (2015). Students's Scientific Reasoning About Global Warming. Proceedings of 2nd International Seminar on Mathematics, Science, and Computer Science Education (MSCEIS).

[5] Ardianto, D., \& Herawati, D. (2016). Kualitas Argumentasi Mahasiswa Calon Guru Biologi pada Isu Sosiosaintifik. Universitas Pakuan: Laporan Penelitian.

[6] Brian R. Belland, K. D. (2011). Problem-based learning and argumentation: testing. Springer Science+Business Media, 39, 667-694. doi:DOI 10.1007/s11251-010-9148-z 
[7] Chiu, M. M. (2008). Effects of argumentation on group micro-creativity:Statistical discourse analyses of algebra students'. Contemp. Educ. Psychol, 33, 382-402.

[8] Cho, K.-L., \& Jonassen, D. H. (2002). The Effects of Argumentation Scaffolds on Argumentation and Problem Solving. ETR\&D, 50(3), 5-22.

[9] Oh, S., \& Jonassen, D. (2007). Scaffolding online argumentation during problem solving. Journal of Computer Assisted Learning, 95-110. doi:10.1111/j.1365-2729.2006.00206.x

[10] Tawfik, A., \& Jonassen, D. (2013). The effects of successful versus failure-based cases on argumentation while solving decision-making problems. Education Tech Research, 385-406. doi:10.1007/s11423-013-9294-5

[11] Tawfik, A. A. (2017). Do cases teach themselves? A comparison of case library prompts in supporting problem-solving during argumentation. Educational Technology, Research and Assessment. doi:10.1007/s12528017-9136-2

[12] Fee, S. B., \& Belland, B. R. (2012). The Role of Criticism in Understanding Problems Solving. New York: Springer.

[13] Kintani, Y., Ali, M., \& Endang, B. (2013). Sikap Percaya Diri dalam Proses Pembelajaran Pada Anak Usia 5-6 Tahun Segedong. Jurnal Pendidikan dan Pembelajaran, 2(10), 1-11. Retrieved from http://jurnal.untan.ac.id/index.php/jpdpb/article/ view/3590/3607

[14] Mirhan, \& Jusuf, J. B. (2016). Hubungan Antara Percaya Diri dan Kerja Keras dalam Olah Raga dan Ketrampilan Hidup. J u r n a l O l a h r a g a $P r e s t a s i, 12(1)$. Retrieved from https://media.neliti.com/media/publications/115 487-ID-hubungan-antara-percaya-diri-dankerja-k.pdf

[15] Afriani. (2016). Pengaruh Ketermpilan Berkomunikasi Sains dan sikap Bandar Lampung: Universitas Lampung. Retrieved from http://digilib.unila.ac.id/23854/3/SKRIPSI\%20T ANPA\%20BAB\%20PEMBAHASAN.pdf 